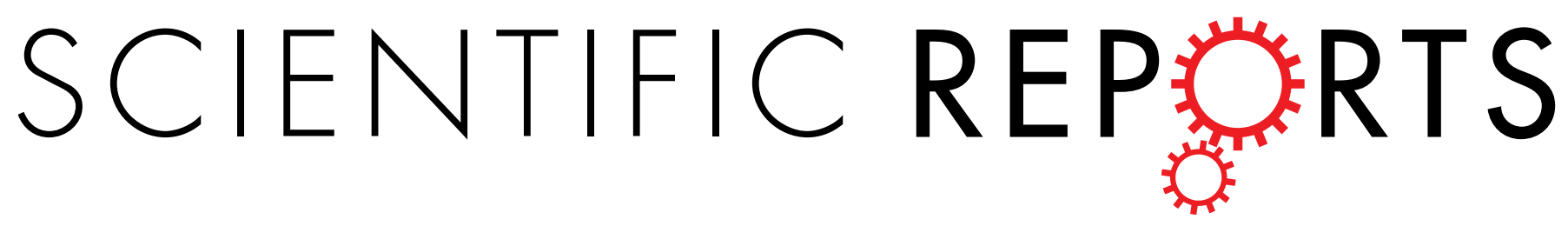

\title{
OPEN Corrigendum: High-level expression of improved thermo-stable alkaline xylanase variant in Pichia Pastoris through codon optimization, multiple gene insertion and high- density fermentation
}

Yihong Lu, Cheng Fang, Qinhong Wang, Yuling Zhou, Guimin Zhang \& Yanhe Ma

Scientific Reports 6:37869; doi: 10.1038/Srep37869; published online 29 November 2016; updated on 16 March 2017

This Article contains an error in the $\mathrm{x}$-axis labelling of Figure 5. The correct Figure 5 appears below as Figure 1.

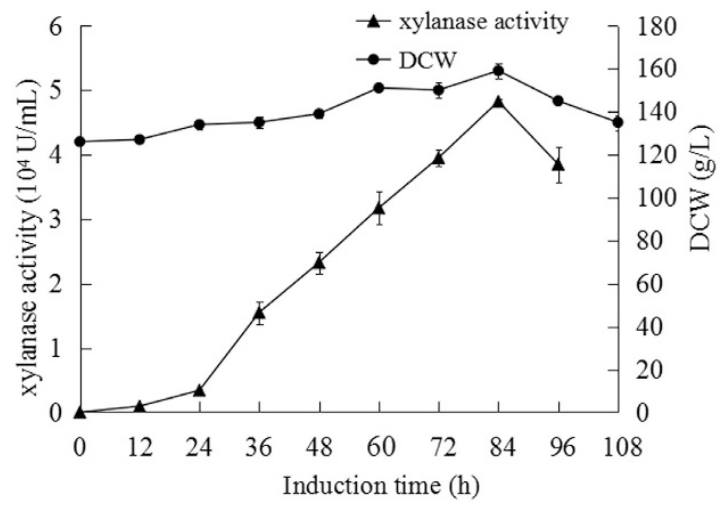

Figure 1.

(c) (i) This work is licensed under a Creative Commons Attribution 4.0 International License. The images or other third party material in this article are included in the article's Creative Commons license, unless indicated otherwise in the credit line; if the material is not included under the Creative Commons license, users will need to obtain permission from the license holder to reproduce the material. To view a copy of this license, visit http://creativecommons.org/licenses/by/4.0/

(C) The Author(s) 2017 